\title{
酸素電極法による香辛料の酸化防止効果の測定
}

(昭和 61 年 2 月 14 日受理)

\begin{abstract}
平山晃久* 山崎真美*
渡辺徹 志*

小野真由美* 福井昭三*

\section{Measurement of Antioxidant Activity in Spices by an Oxygen Electrode Method}

\author{
Teruhisa Hirayama, Mami Yamazaki, Tetsushi Watanabe, \\ Mayumi ONo and Shozo FUKUI
}

(Kyoto Pharmaceutical University: 5-Nakauchi-cho, Misasagi, Yamashina-ku, Kyoto, Japan)

A simple and rapid determination method for antioxidant activity by using an oxygen electrode was developed. The procedure is as follows. Oil emulsion $(1.2 \mathrm{ml})$, which contained $0.18 \mathrm{~g}$ of safflower oil, and $0.29 \mathrm{ml}$ of Tween 20 , was added immediately to $46.3 \mathrm{ml}$ of $0.05 M$ phosphate buffer ( $\mathrm{pH} \mathrm{7.2)} \mathrm{in} \mathrm{a} 50 \mathrm{ml}$ centrifuging tube. The contents of the tube were stirred continually and maintained at $45^{\circ} \mathrm{C}$. Immediately after addition of the emulsion, $2.5 \mathrm{ml}$ of hemin solution was added. The oxygen electrode was inserted quickly into the tube, and the oxygen uptake from the reaction solution was recorded automatically. The antioxidative effects of spices in this system were tested. Of 15 methanol extracts of spices tested, 7 were effective. The methanol extract of cinnamon (1\% ethanol solution) had the greatest activity (induction period $=49.8 \mathrm{~min} ; 50 \%$ oxygen consumption period $=69.8 \mathrm{~min}$ ), where as the induction and $50 \%$ oxygen consumption periods of $1 \%$ butylated hydroxytoluene, used as a positive control, were 11.9 and $21.0 \mathrm{~min}$, respectively.
\end{abstract}

(Received February 14, 1986)

Key words: 酸素電極法 oxygen electrode method; 酸化防止效果 antioxidative effect; 香辛科 spices; シナモン cinnamon;オールスパイス all spice

\section{緒 言}

現在食品に対する酸化防止剂としてジブチルヒドロキ シトルェン (BHT), ジブチルヒドロキシアニソール (BHA) などが使用されているが，これらは合成食品添 加物であり, 特に BHA については一部で安全性に疑問 も提起されており新たな酸化防止剤が望まれている。 た現在使用されている $\alpha$-tocopherol は酸化防止力とし てはそ机程強力なものではなく, 新しい天然由来の酸化

\footnotetext{
* 京都薬科大学：京都市山科区御陵中内町 5
}

\section{防止剤の開発が急務である.}

古来より香辛料はその香り，味など食欲增進効果以外 に魚肉，畜肉類などの保存の目的でも使用されてきてお り，その抗菌効果以外にローズマリー1)などで実証され ているょらに酸化防止効果も予想される.

また現在のところ, 酸化防止効果の測定法としては酸 素の吸収量を測定する重量法 ${ }^{2)}$, ワールブルグ検圧計を 用いる酸素吸収法 ${ }^{3}$ 及及び 溶存酸素計を用いる測定法4) 6) がある.これらのらち最も迅速簡便であり, 酸素吸収量 の経時变化が容易に測定できる溶存酸素計を用いる方法 
について検討した．溶存酸素計法としては Berner らの 方法5) が報告されているが追試したところ再現性にそし い結果が得られたので, 反応容器, 使用する油脂などを 変えて一部改良し，再現性の良い測定法を確立できた. そこでこの方法を用いて入手できた香辛料十数種のメタ ノールェキスについて酸化防止効果の測定を行い, 若干 の知見が得られたので報告する.

\section{実験方法}

\section{1. 試薬}

紅花油，いわし油：山桂産業株式会社製

ごま油：半井化学薬品 (株) 製

ヘミン: hemin, bovine, Type 1 crystalline Sigma 社製

BHT, Tween 20: 和光純薬工業(株)製試薬一級

BHA， $\alpha$-tocopherol：半井化学薬品(株)製試薬一級

有機溶媒：市販試薬一級品を蒸留後使用

他の試薬は特級品をそのまま使用した。

香辛料：市販の粉末香辛料15種を用いた。ローレル， クローブ, シナモン，オールスパイス，七ージ，タイム， カルダモン, ナツメッグ, ブラックペパー, ホワイトペ パー, サンショウ, クミンシード, ローズマリーはエス ビー食品(株)製，オレガノとレッドペパーはライオン

(株)製を用いた。

\section{2. 装置}

スターラー：東京理化器械製 Hotting stirrer

溶存酸素計：電気化学計器 (株) DO-31 型

酸素電極：ロングライフ型溶存酸素電極 $7612-5 \mathrm{D}$ 型 記録計：日本分光 $\mathrm{RC}-125 \mathrm{M}$

\section{3. 実験 操 作}

試験溶液の調製：酸化防止効果判定のための対照試料 として既存酸化防止剤である BHA, BHT 及び $\alpha$-tocopherol を用い, 試験対象としては下記のように調製し た香辛料のメタノールェキスを用いた. BHA, BHT 及 び $\alpha$-tocopherol はメタノールに溶解して $1 \%$ 及び $2 \%$ の溶液を作製した．香辛料は粉末試料 $5 \mathrm{~g}$ を採りメタノ ール $50 \mathrm{ml}$ を加え, 水浴中 $60^{\circ}$ で 1 時間抽出を 2 回繰 返し, 抽出液を合して減圧下 $40^{\circ}$ 以下で濃縮乾固した.

ここに得た抽出物をメタノールに溶解し $10 \%$ の試験溶 液を作製した。

ヘミン溶液：Berner らの方法 ${ }^{5)}$ に従い, $52 \mathrm{mg}$ のへ ミンを蒸留水 $75 \mathrm{ml}$ に憼濁し，10\% 水酸化カリウム溶 液 2〜4 滴を加えて溶解し蒸留水を加えて $100 \mathrm{ml}$ とし た。

酸化防止効果測定： $50 \mathrm{ml}$ のビーカーにメタノールに 溶解した試験溶液 $0.1 \mathrm{ml}$, 油脂 $0.75 \mathrm{~g}$ 及び Tween 20 $1.2 \mathrm{~g}$ を入れ，これに $45^{\circ}$ に加温した $0.1 M$ リン酸緩 衝液 (pH 7.2) $3 \mathrm{ml}$ を加え, $20 \mathrm{ml}$ の注射器を用いて約 20回吸引，排出を繰返し均一に乳化させる. 乳化後ただ ちに乳化液の $1.2 \mathrm{ml}$ を採り, あらかじめ $50 \mathrm{ml}$ の遠沈

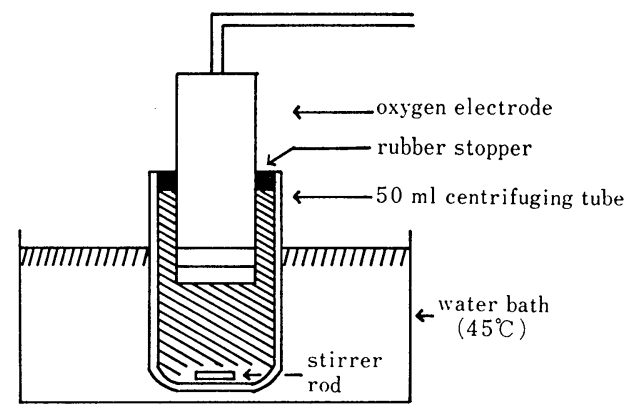

Fig. 1. Apparatus for $\mathrm{O}_{2}$ consumption method

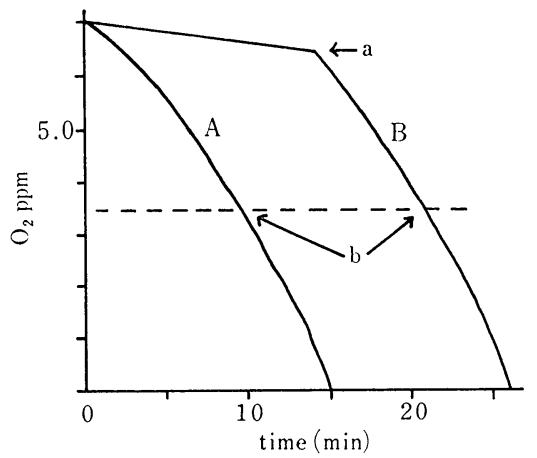

Fig. 2. $\mathrm{O}_{2}$ consumption curves of oil with and without antioxidant
A: oil
B: oil+antioxidants
a: induction period
b: $50 \% \mathrm{O}_{2}$ consumption period

管に $0.05 M$ リン酸緩衝液 ( $\mathrm{pH} \mathrm{7.2)} 46.3 \mathrm{ml}$ を入れ, 液温を $45^{\circ}$ に保ったものの中に加える（油脂濃度約 180 $\mathrm{mg} / 50 \mathrm{ml}$ 反応液).ついでへミン溶液 $2.5 \mathrm{ml}$ を一気に 加え (ヘミン濃度 $1.3 \mathrm{mg} / 50 \mathrm{ml}$ 反応液), ただに Fig. 1 のようにヘッドスペース部及び電極部に空気が 残留しないようにゴム栓付き酸素電極を插入して密閉 し，回転子で攪拌しながら溶存酸素濃度を測定し，レコ ーダーを用いて経時的に記録する．ただし酸素電極は測 定前から $45^{\circ}$ の水に浸し温度变化を与えないようにす る. 別に試験溶液のかわりにメタノール $0.1 \mathrm{ml}$ を用い 以下同様に操作して溶存酸素濃度を測定しブランク值と する.

\section{結果と考察}

\section{酸素電極を用いる酸化防止効果測定法の検討}

すでに Berner $5^{5)}$ は測定懸濁液中の油脂含量, 油脂 と酸化触媒であるへミンとの量関係及び七面鳥油を用い たときの反応温度などについて検討しており，これによ る合成酸化防止剂の酸化防止効果を溶存酸素吸収開始時 期すなわち誘導期を用いて測定している，そこで今回香 

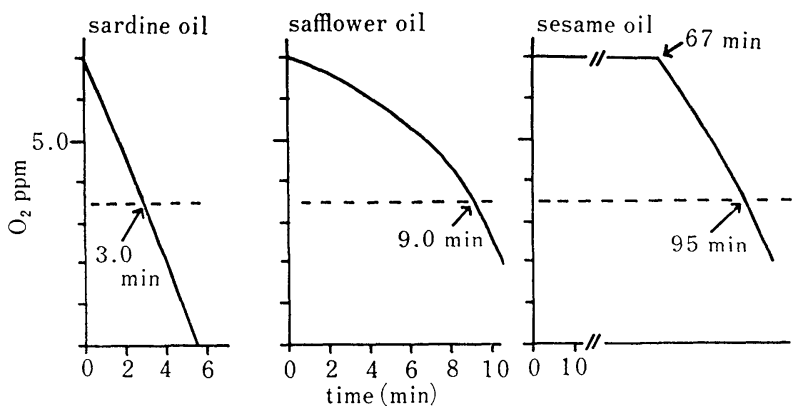

Fig. 3. $\mathrm{O}_{2}$ consumption curves in various oils $\left(45^{\circ} \mathrm{C}\right)$

辛料の酸化防止効果を知る目的で，反応溶液としては Berner らと同一組成のものを使用し，油脂の種類及び 反応温度条件について検討を加えた．温度条件について $45^{\circ}$ 以下での条件も検討したが，初期の溶存酸素濃度は 高く感度は上るが，逆に過酸化の速度が遅く長時間を要 するため今回は反応温度を $45^{\circ}$ に統一した。 また Ber ner らの方法ではマイヤーフラスコを容器として用いて いるため，䚓拌により空気中の酸素が反応溶液中へ再吸 収され，追試の結果再現性が得られなかった。そこで Fig. 1 に示すように $50 \mathrm{ml}$ の遠沈管を反応容器とし, 酸素電極にゴム栓を取り付け空気の入らない，さらにへ ッドスペースのない状態で実験を行ったところ再現性の 高い結果が得られた。

Fig. 2 には本法で測定した典型的な油脂の過酸化に よる溶存酸素減少曲線 $(\mathrm{A})$ を示してある.これに酸化防 止剤を添加することによって誘導期の延長がみられ，つ いでA と同様 の酸素減少曲線を描くのが一般的である (B). そこで今回は誘導期 a (min), $50 \%$ 酸素減少時間 b (min) 及び $50 \%$ 酸素減少時における酸素減少速度 c $\left(\mathrm{O}_{2} \mathrm{ppm} / \mathrm{min}\right)$ の三者を指標として酸化防止効果を比較 することとした。すなわち酸化防止剤の添加によって c は一定であるが，a 及び b の延長が見られると予想され る.

\section{実験に用いる油脂の選択}

Fig. 3 にはいわし油，紅花油及びごま油を用いたとき の対照の溶存酸素減少曲線を示す。いずれの場合も反応 温度 $45^{\circ}$ における初期溶存酸素濃度は $7.0 \mathrm{ppm}$ と安定 していた.

不飽和高級脂肪酸の多いいわし油を実験用油脂とした 場合, $\mathrm{b}=3 \mathrm{~min}$ と酸素の減少が速かであり実験時間が 短かくてすむ利点があるが, 反面過酸化の過程が早過ぎ て酸化防止剂の効果の判別が困難であった。半乾性油の ごま油を用いた場合は $\mathrm{a}=67 \mathrm{~min}, \mathrm{~b}=95 \mathrm{~min}$ と長時間 を要し実験用油脂として不適当であった。リノール酸を 主構成脂肪酸とする紅花油は誘導期を持たず， $b=9.0$ 土 $1.0 \mathrm{~min}(\mathrm{n}=3), \mathrm{c}=2.01 \pm 0.35 \mathrm{O}_{2} \mathrm{ppm} / \mathrm{min}(\mathrm{n}=3)$ と
Table 1. Prolonged Effects of Antioxidants on $\mathrm{O}_{2}$ Consumption by Safflower Oil at $45^{\circ} \mathrm{C}$

\begin{tabular}{|c|c|c|c|}
\hline Sample & a & b & c \\
\hline Control & 0 & 9.0 & 2.01 \\
\hline $\mathrm{BHT} 1 \%$ & 11.5 & 21.0 & 1.17 \\
\hline $2 \%$ & 46.0 & 58.0 & 1.95 \\
\hline BHA $1 \%$ & 12.0 & 26.5 & 1.56 \\
\hline $2 \%$ & 48.5 & 62.0 & 1.44 \\
\hline \multirow[t]{2}{*}{$\alpha \cdot$ Tocopherol } & 0 & 18.0 & 2.42 \\
\hline & 0 & 24.5 & 1.73 \\
\hline
\end{tabular}

a: induction period $(\min$, mean value $(\mathrm{n}=3))$

b: $50 \% \mathrm{O}_{2}$ consumption period (min, mean value $(\mathrm{n}=3)$ )

c: $\mathrm{O}_{2}$ consumption rate $\left(\mathrm{O}_{2} \mathrm{ppm} / \mathrm{min}\right.$, mean value $(\mathrm{n}=3))$ at $50 \% \mathrm{O}_{2}$ consumption period.

$50 \%$ 酸素减少時間も適当であり, 再現性も認められ実 験用油脂としては最適と思われたので以後の実験にはす べて紅花油を用いた。

\section{市販酸化防止剤の酸化防止効果}

Table 1 には今回の酸素電極法による BHT, BHA 及 び $\alpha$-tocopherol のそれぞれ $1 \%$ 並びに $2 \%$ ×タノー 儿溶液 $0.1 \mathrm{ml}$ 添加による酸化防止効果測定結果を示し ている. BHA，BHT の c 值は対照に比べてそれ程変動 はなかったが, $\mathrm{a}$ 值, $\mathrm{b}$ 值ともに濃度依存的に增加が認 められた。 また $\alpha$-tocopherol については $1 \%$ 及び $2 \%$ 溶液ともに誘導期の形成（a 值の増加）が認められず BHT, BHA に比べて酸化防止効果の弱いことが判っ た.

\section{市販香辛料メタノールエキスの酸化防止効果}

Table 2 には 15 種の市販香辛料のメタノールエキス の酸化防止効果を示した. Table 2-a に示した香辛料は $\mathrm{a}$ 值の増加が認められず b 值のわずかな增加あるいは 減少が見られたものであり，これらには酸化防止効果は ほとんどないものと考えられる. さらに対照の $b=9.0$ min に対してブラックペパーは $7.0 \mathrm{~min}$ ，ホワイトペ ペーは $6.0 \mathrm{~min}$ と短かく，これらの成分中には過酸化 
